\title{
Urban Market-Gardening in Parakou (Republic of Benin): Spatial Dynamics, Food Security, Protection of the Environment and Creation of Employments
}

\author{
Abdoul-Ramane Abdoulaye*, Aboudou Yacoubou Mama Aboudou Ramanou \\ Département de Géographie et Aménagement du Territoire, Faculté des Lettres, Arts et Sciences Humaines, \\ Université de Parakou, Parakou, République du Bénin \\ Email: *awar1963@yahoo.fr, aboudou ramanou@yahoo.fr
}

Received 18 May 2015; accepted 25 July 2015; published 28 July 2015

Copyright (C) 2015 by authors and Scientific Research Publishing Inc.

This work is licensed under the Creative Commons Attribution International License (CC BY). http://creativecommons.org/licenses/by/4.0/

(c) $\underset{\mathrm{EY}}{\mathrm{B}}$ 0pen Access

\begin{abstract}
Nowadays, African cities are subjected to upsets which result from the extraordinary growth of urban populations. The growth of the population of cities has induced some changes in the structure of the activity of those cities. Agriculture which was formerly confined to the countryside henceforth develops in the urban area and occupies a preponderant place as a strategy of survival, of insertion and of food supplying of the city-dwellers. It has become an activity integrated to the urban tissue through systems of occupying and exploitation of land in the urban area. Population growth $(4.81 \%)$ between 2002 and 2013 is a critical poverty rate $(65 \%)$ of the population of Parakou city, entailing a misery perceptible in all its social and economic dimensions. The marketgardening activity has integrated itself to the urban tissue. The objective of this study is to understand how urban agriculture through market-gardening can be a solution for rural farmers who have moved to Parakou city. In this study, documentary research, interviews and field observation are used for data collection. The main results to be signaled among others are: evolution and status of the market-gardening areas in Parakou, the reduction of food insecurity with the permanent availability in quantity and in quality of market-gardening products accessible to the population: the protection of the environment through the drainage of the urban area and the preservation of the diversity of vegetables; the increase of the income of the households of the farmers and the creation of employments.
\end{abstract}

\section{Keywords}

Urban Agriculture, Food Security, Market-Gardening Channel, Land Dynamics, Protection of the

${ }^{*}$ Corresponding author.

How to cite this paper: Abdoulaye, A.-R. and Ramanou, A.Y.M.A. (2015) Urban Market-Gardening in Parakou (Republic of Benin): Spatial Dynamics, Food Security, Protection of the Environment and Creation of Employments. Journal of Geoscience and Environment Protection, 3, 93-103. http://dx.doi.org/10.4236/gep.2015.35011 


\section{Environment, Employment, Parakou}

\section{Introduction}

Nowadays, African cities are subjected to upsets which result from the extraordinary growth of urban populations. According to the report of the United Nations Funds for Population (UNFP) on the state of world population 2007, in 2008, more than half of the population of the globe, or 3.3 billion of inhabitants, will live in urban areas. And the rhythm of that urbanization is so fast that between 2000 and 2030, the urban population of Africa will pass from 294 to 742 million. In tropical Africa, the fast growth of the urban population makes the supplying of cities a major stake of food security policies.

The growth of the population of cities has entailed changes in the structure of the activity of those cities. Agriculture which was formerly confined to the countryside henceforth develops in the urban area and occupies a preponderant place as a strategy of survival, of insertion and of food supplying to city-dwellers. It has become an activity integrated to the urban tissue through systems of occupying and exploitation of land in the urban area [1]. The feeding, social, economic and environmental functions of urban agriculture make it a potential vector of lasting development in the cities of the North as in those of the South. This is what justifies the ever-increasing interest in all directions for that activity [1]. According to the 2013 General Population and Home Census [2], 60\% of the population of Parakou is poor. Parakou is confronted with a galloping demography, with a growth rate of 2.81\% between 2002 and 2013. The situation is the result of an increase of the movements from countrysides to Parakou city. The intense rural exodus thus observed can be explained according to [3], by the quest, by young people, of a higher income.

Despite the fact that cities continue to depend on rural agriculture, urban and out-of-town agriculture will provide considerable quantities of food (mainly of perishable products) and will improve the food security of poor urban. It is estimated that almost 15 percent of world food products come from urban agriculture and that 70 percent of the urban households of developing countries participate in these agricultural activities. That self-production can satisfy up to 60 percent of the food needs of a family. It also improves nutrition and allows the households to use a larger part of their income for other fees such as schooling and health. Moreover, urban agriculture contributes to the creation of micro-enterprises specialized in the production of compost or the transformation and the sale of food products [4].

Neo-urban households have adopted survival strategies among which urban agriculture is the most popular one. That agriculture puts at the disposal of the population various agricultural products. In addition, urban agriculture, while being a generator of income and a creator of employment, also constitutes an effective means of the drainage of the area through the collection and revalorization of biodegradable organic waste, serving as fertilizer for agricultural production in a polluted city like Parakou [5].

The present study aims at understanding how urban agriculture through market-gardening can be a solution of economic survival for rural farmers who have moved to Parakou city. More specifically, it allows: i) to understand the strategies of occupying and of development of urban areas for the conduct of market-gardening and ii) to bring out the economic and environmental advantages of the market-gardening sector of Parakou.

\section{Methodology}

\subsection{The Study Zone and Its Physical Characteristics}

The study has been carried out in the urban perimeter of the Commune of Parakou. The study zone spreads on a surface of $66 \mathrm{~km}^{2}$ or approximately $15 \%$ of the surface of the commune [6]. It is situated between $9^{\circ} 13^{\prime}$ and $9^{\circ} 23^{\prime}$ of North latitude and $2^{\circ} 35^{\prime}$ and $2^{\circ} 40^{\prime}$ of East longitude (Figure 1 ). The study zone is limited, in the North by the hills of Guêma, in the West by the river of Thian, in the East by the river of Kabounare at Baka quarter and in the South by the depression of Tokoumaro. The choice of the zone is motivated by the availability of an underworld (40 ha) favourable to urban agriculture, specifically market-gardening.

Parakou city benefits from a wet tropical climate of the sudanian type characterized by an annual succession of two seasons (Figure 2): a dry season which lasts three months, from mid-October to mid-April and a rainy season which occupies the rest of the year and concentrates $79 \%$ of rainy events. The dry season, severe between 

460000

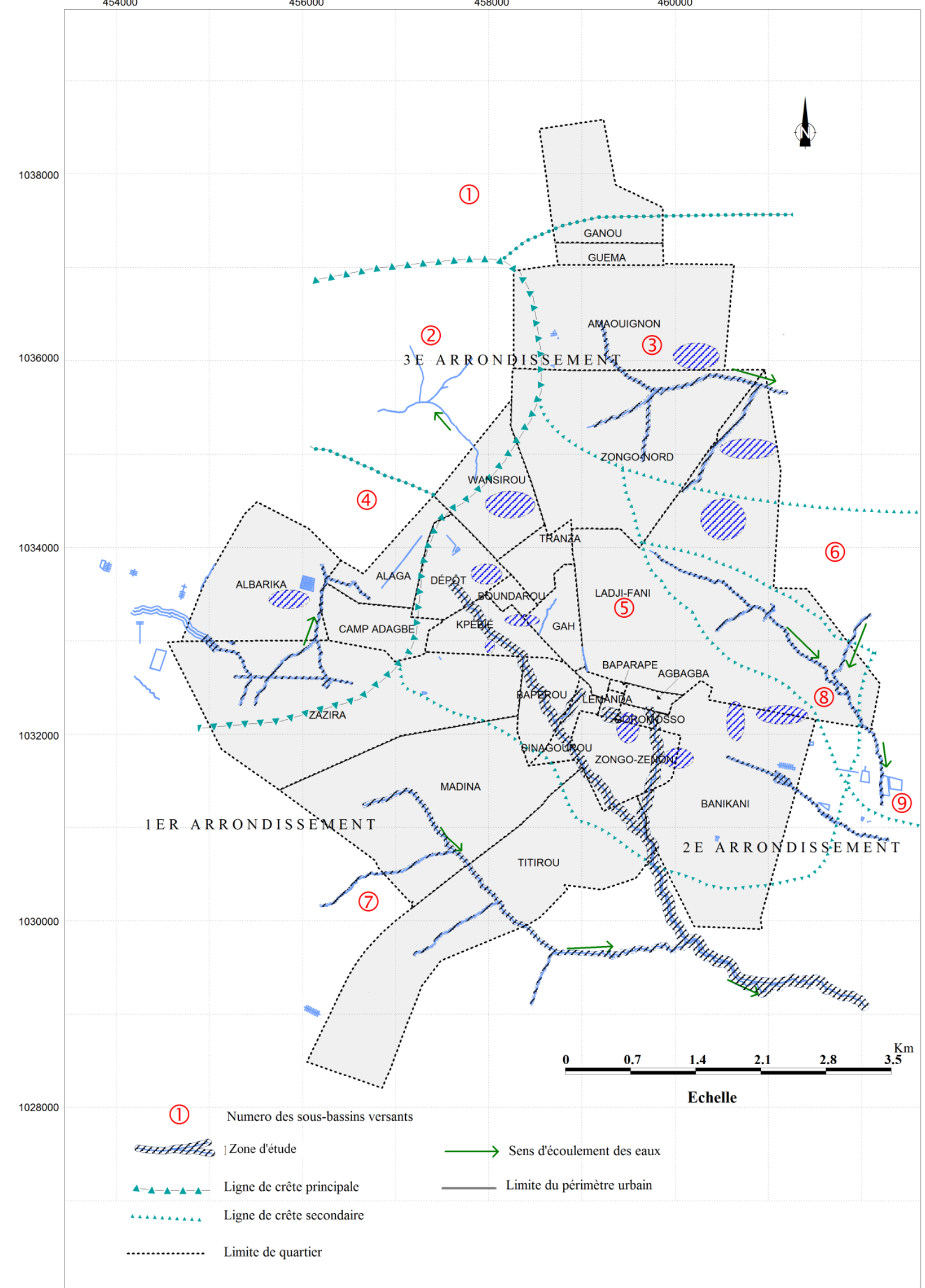

Figure 1. Localization of the study zone. 


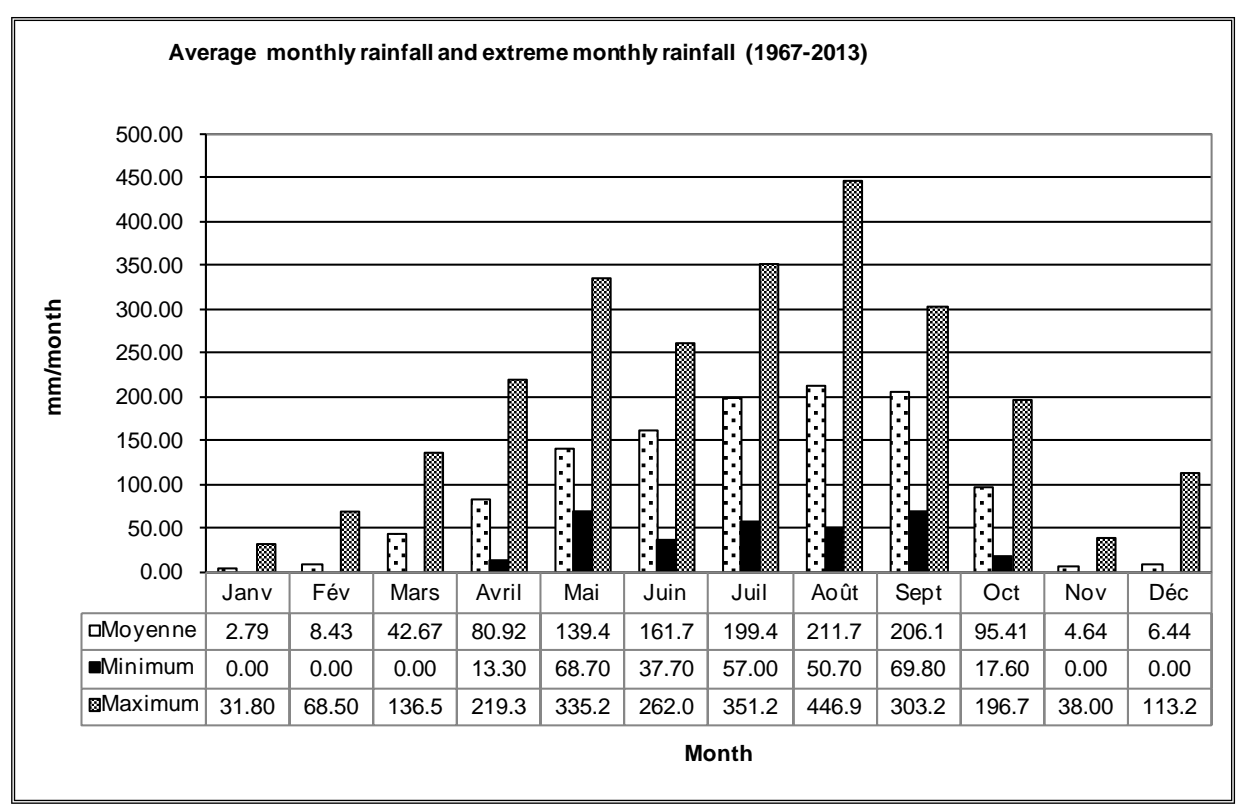

Figure 2. The monthly evolution of rainfalls, maximum, minimum and average. Source: Statistics of ASECNA, 2014.

December and February, is marked by the harmattan (a cold and dry wind). The annual average rainfalls are of $1200 \mathrm{~mm}$.

The lower depths (study area) are swampy Savannah grasslands, thickets of bamboo (Bambusa arundinacca).

According to [7], Parakou city has three types of soils which are: ferruginous soils with sesquioxydes of iron and of manganese which occupy $72 \%$ of the surface of the study zone, thus the most expanded ones, then ferralitic soils which occupy $20 \%$ of the study zone, thus less represented than the first, and finally hydromorph minerals or not much humiferous soils which occupy $8 \%$ of the surface of the study zone, thus very poorly represented.

\subsection{Sampling and Data Collection}

In this study, the three main methods of data collection used are: documentary research, interviews and field observation. The documentary review has consisted in the consultation of general and specific works, of existing articles on urban agriculture. All this has permitted to better apprehend the research topic and to master its different contours.

Interviews have been carried out in the fifteen (15) big market-gardening sites (surface superior or equal to two (2) hectares) out of the forty-eight (48) that the study zone counts; close to 45 market-gardeners: or three (03) market-gardeners ( 01 woman and 02 men) per site. The technique of sample by cluster has been used. The unit of cluster is the site. The choice of the fifteen sites is motivated by the existence of associations of market-gardeners. The sampling at the level of each site is reasoned according to the sex, then probabilistic within each modality of sex. The number of men compared to that of women is proportional to the weight of each sex on the site.

The questionnaire administered to each surveyed person concerned qualitative elements (professional experience, level of instruction, type of training, cultivated plants, farming practices, fertilizers used, period of applying, channels of supply, way of acquisition of the exploited plots, the relationships with the first occupants, their origin) and quantitative elements (the market-gardeners' age, the cultivated surfaces, the doses of fertilizers used, the number of days between the treatments and the harvest). The data collection has taken place from 2008 to 2013, or for five (05) years.

The semi-structured individual interviews with the different actors (politico-administrative and local authorities, customary chiefs, market-gardeners), some focus groups (groups of market-gardeners, of natives, of migrants, of women, of men, etc.) and some direct observations (observation of the activities, of the work tools and 
of the actors' practices) have permitted to complete the data collected from the surveyed people.

\subsection{Treatment of the Data}

In our approach, the qualitative data have been recorded on a magnetic tape and completely transcribed on paper later. However, only some extracts of interviews have been used in the analysis of the market-gardening channel. The treatment of the quantitative information with the help of the software Sphinx Lexica, after a preliminary work of encoding, has permitted to obtain some synthesis tables and some orders of highness of the market-gardening channel. A botanic analysis has been made in order to determine the number of species and varieties of plants cultivated on the one hand, their alimentary and nutritious values on the other hand. A typology of the commercialized organs has been achieved.

The spatio-temporal dynamics of the market-gardening perimeters has been analyzed with the help of the Geographical Data Processing System (SIG). In the field, the GPS (World Positioning System) has been used to make the statement of the market-gardening perimeters. Those data have been used with the software Arc View to achieve the map of the market-gardening perimeters (Figure 1) and calculate the exploited surfaces.

\section{Results}

\subsection{Dynamics of the Market-Gardening Surfaces}

The market-gardening perimeters of Parakou city are sorted out into the three districts that the Commune of Parakou is made up of and situated in the underworlds. The localization, the surface, the dynamics from 2008 to 2013 and the status of the market-gardening sites of Parakou are presented in Table 1. From the analysis of Table 1, it stands out that the total surface of market-gardening perimeters has progressed from 121 hectares between 2008 and 2013, passing from 79 hectares to 200 hectares, or an increase of 153\%. Among the surveyed market-gardeners, $60 \%$ of the market-gardeners occupy the land estate of the commune, $27 \%$ exploit hired lands and only $13 \%$ have acquired family lands.

\subsection{A Diversified Production and the Contribution of Food Security}

The species which that study has leant over are: the fruit vegetables (eggplant, okra), the root vegetables (carrot) and the leafy vegetables (garden marjoram). The evolution of the market-gardening production of those species between 2008 and 2013 in Parakou is presented by Figure 3.

From the analysis of Figure 3, it stands out that the market-gardening production has progressed from 29,765 tons between 2008 and 2013, passing from 8938 tons to 38,703 tons, or a growth rate of 54\%. The alimentary and nutritious value of vegetables per $100 \mathrm{~g}$ of eatable stuff is presented in Table 2.

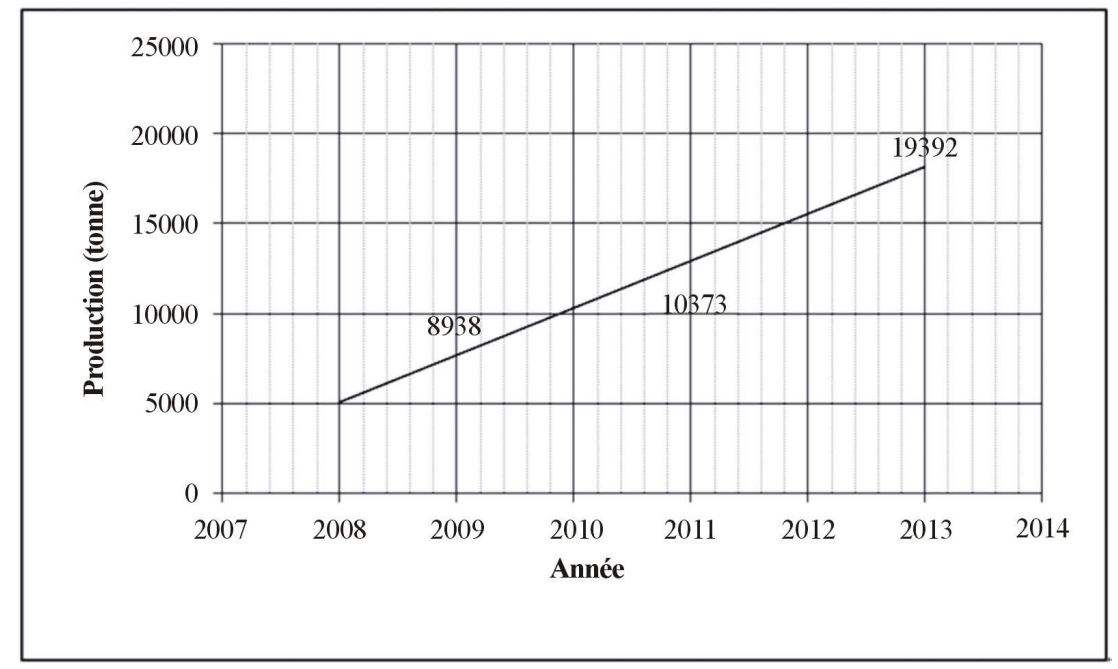

Figure 3. Evolution of the market-gardening production from 2008 to 2013. Source: Results of the analysis of the data of the surveys, 2013. 
Table 1. The dynamics and the status of the market-gardening sites of Parakou from 2008 to 2013.

\begin{tabular}{|c|c|c|c|c|c|c|}
\hline No. of order & Quarter & Name of the site & $\begin{array}{c}\text { 2008-2009 } \\
\text { surfaces (ha) }\end{array}$ & $\begin{array}{c}\text { 2010-2011 } \\
\text { surfaces (ha) }\end{array}$ & $\begin{array}{c}\text { 2012-2013 } \\
\text { surfaces (ha) }\end{array}$ & $\begin{array}{c}\text { Status of the } \\
\text { site }\end{array}$ \\
\hline \multicolumn{7}{|c|}{ 1st District } \\
\hline 1 & Guinsi & Guinsi Tora & 1.5 & 2 & 7 & Commune \\
\hline 2 & Tourou & Sonkpian & 3.5 & 3.5 & 8.5 & Commune \\
\hline 3 & Madina & Adessina & 1.75 & 5.75 & 10.75 & Commune \\
\hline \multicolumn{3}{|l|}{ Total } & 6.75 & 11.25 & 26.25 & \\
\hline \multicolumn{7}{|c|}{ 2nd District } \\
\hline 4 & Koroborou & Diboudi & & 2.5 & 4.5 & family \\
\hline 5 & Koroborou & Kabounare & & 2 & 8 & Commune \\
\hline 6 & Sokounon & Dam & & 4 & 6.75 & hiring \\
\hline 7 & Ladjifarani & Cabounare & & 2.75 & 4 & hiring \\
\hline 8 & Madjaton & Madjaton & 7.25 & 7.5 & 10.5 & Commune \\
\hline 9 & Banikani & Toko kpe kara & & 12 & 18 & Commune \\
\hline 10 & Bawèra & Kokoura & & 12 & 22 & Commune \\
\hline 11 & Madjaton & Dama & & 6.5 & 10 & familiale \\
\hline 12 & Arafat & Kaabounaré & & 2 & 12 & Commune \\
\hline Total & & & 7.25 & 43.75 & 95.75 & \\
\hline \multicolumn{7}{|c|}{ 3rd District } \\
\hline 13 & $\begin{array}{l}\text { Kpassa } \\
\text { Gambou }\end{array}$ & Monastery & 2 & 5 & 7 & location \\
\hline 14 & Wansirou & Koubouré & 3 & 3 & 3 & location \\
\hline 15 & Zongo II & Zongo II & 60 & 57 & 68 & Commune \\
\hline Total & & & 65 & 65 & 78 & \\
\hline \multicolumn{2}{|c|}{ GENERAL TOTAL } & & 79 & 120 & 200 & \\
\hline
\end{tabular}

Source: Results of the analysis of the data of the surveys, 2013.

It stands out from the analysis of Table 2, that the leafy vegetables cultivated in Parakou occupy a place of choice given their interesting properties, notably a rapid growth, a production facility and a high nutritious value.

\subsection{Protection of the Environment through the Drainage of the Urban Area}

Parakou city enormously produces waste, as it is the case of three municipal markets illustrated in Table 3 . The needs in composts of six market-gardening perimeters of Parakou are contained in Table 4.

From the crossed analysis of Table 3 and Table 4, it stands out that the annual need of the six market-gardening perimeters of Parakou is reached.

Of all the waste produced in the three markets of Parakou ( $33580 \mathrm{~m}^{3}$ per year), the market-gardening channel consecrates $18436 \mathrm{~m}^{3}$ per year to the revalorization through burying (green fertilizers) and through composting for the needs in compost (Table 4). This corresponds to $55 \%$ of recycled waste to produce 6280 tons of compost necessary per year (Table 5).

\subsection{Creation of Employments and Increase of Income}

\subsubsection{Source of Employment}

It is revealed according to the data of CARDER/BORGOU-ALIBORI (2013), that the census of a total of 420 market-gardeners has been taken in the market-gardening perimeters of Parakou for the year 2013 among whom 
Table 2. Alimentary and nutritional value of vegetable per $100 \mathrm{~g}$ of eatable stuff.

\begin{tabular}{|c|c|c|c|c|c|c|c|c|c|c|c|c|}
\hline \multirow{3}{*}{ Crops } & \multicolumn{10}{|c|}{ Eatable nutritious stuff } & & \\
\hline & \multirow[t]{2}{*}{ Water $\mathbf{g}$} & \multirow[t]{2}{*}{$\begin{array}{l}\text { Proteins } \\
\mathrm{g}\end{array}$} & \multirow[t]{2}{*}{$\begin{array}{c}\text { Cellulose } \\
\mathbf{g}\end{array}$} & \multirow[t]{2}{*}{$\begin{array}{c}\text { Calcium } \\
\text { mg }\end{array}$} & \multirow[t]{2}{*}{$\begin{array}{c}\text { Iron } \\
\text { mg }\end{array}$} & \multirow[t]{2}{*}{$\begin{array}{c}\text { Caratein } \\
\text { mg }\end{array}$} & \multirow[t]{2}{*}{$\begin{array}{l}\text { Vitamin } \mathrm{C}, \\
\mathrm{mg}\end{array}$} & \multicolumn{3}{|c|}{ Other Vitamins (mg) } & \multicolumn{2}{|c|}{$\begin{array}{c}\text { Energizing } \\
\text { value }\end{array}$} \\
\hline & & & & & & & & $\begin{array}{l}\text { Thiamin } \\
\text { (B1) }\end{array}$ & $\begin{array}{l}\text { Riboflavin } \\
\text { (B2) }\end{array}$ & $\begin{array}{l}\text { Niacin } \\
\text { (PP) }\end{array}$ & & \\
\hline \multicolumn{13}{|c|}{ Fruit vegetables } \\
\hline Eggplant & 92 & 1.6 & 1.5 & 22 & 0.9 & - & 6 & 0.08 & 0.07 & 0.7 & 108 & 26 \\
\hline Okra & 90 & 1.8 & 0.9 & 9 & 10 & 0.1 & 18 & 0.07 & 0.08 & 0.8 & 129 & 20 \\
\hline \multicolumn{13}{|c|}{ Root vegetables } \\
\hline Carrot & 89.6 & 1.1 & 0.9 & 3.6 & 1.2 & 4.2 & 8 & 0.06 & 0.05 & 0.7 & 154 & 37 \\
\hline \multicolumn{13}{|c|}{ Leaf vegetables } \\
\hline & \multicolumn{8}{|c|}{ Eatable nutritious stuff } & \multicolumn{4}{|c|}{ Energizing value } \\
\hline & Water $\mathbf{g}$ & g Protei & ins g & $\begin{array}{c}\text { Cellulose } \\
\mathrm{g}\end{array}$ & $\begin{array}{c}\text { Calcium } \\
\text { mg }\end{array}$ & Iron mg & $\begin{array}{c}\text { Caroten } \\
\text { mg }\end{array}$ & $\begin{array}{l}\text { Vitamin } C, \\
\text { mg }\end{array}$ & \multicolumn{2}{|l|}{$\mathbf{K j}$} & \multicolumn{2}{|c|}{ Kcal } \\
\hline $\begin{array}{c}\text { Garden } \\
\text { marjoram }\end{array}$ & $84-89$ & $93.6-2$ & 4.6 & $1.3-1.8$ & $154-410$ & $02.9-8.9$ & $5.7-6.5$ & 64 & \multicolumn{2}{|c|}{108} & \multicolumn{2}{|c|}{26} \\
\hline
\end{tabular}

Source: [8].

Table 3. Average volumes of waste in cubic meters produced by three markets of Parakou.

\begin{tabular}{ccccc}
\hline Markets & ARZEKE & DEPÔT & TINRE & TOTAL \\
\hline Average volume of waste $\left(\mathrm{m}^{3} /\right.$ day $)$ & 50 & 27 & 15 & 92 \\
Containers/bac $\left(10 \mathrm{~m}^{3}\right)$ & 3 & 2 & 1 & 6 \\
\hline
\end{tabular}

Source: Results of the analysis of the data of surveys, 2013.

Table 4. Needs in composts of six market-gardening perimeters of Parakou.

\begin{tabular}{cccccccc}
\hline $\begin{array}{c}\text { Market-gardening perimeters } \\
\text { maraîchers }\end{array}$ & Tourou & Madina & Banikani & Bawera & Wansirou & Zongo II & Total \\
\hline $\begin{array}{c}\text { Necessary organic waste } \\
\text { (m } \text { (3ear) }^{3 / y}\end{array}$ & 699 & 349 & 2398 & 2398 & 599 & 11,993 & 18,436 \\
$\begin{array}{c}\text { Necessary quantity of } \\
\text { compost (T/year) }\end{array}$ & 238 & 119 & 817 & 817 & 204 & 4085 & 6280 \\
\hline
\end{tabular}

Source: Results of the analysis of the data of surveys, 2013.

Table 5. Synthesis of the management of waste by the market-gardening channel of Parakou.

\begin{tabular}{cccc}
\hline \multirow{2}{*}{$\begin{array}{c}\text { Average volume of waste of three } \\
\text { markets of Parakou (m } \mathrm{m}^{3} / \text { year) }\end{array}$} & \multicolumn{2}{c}{ Compost used in the market-gardening perimeters of Parakou } \\
\cline { 2 - 4 } & Necessary quantities of waste (m $\mathrm{m}^{3} /$ year) & $\%$ & Necessary quantities of compost (T/year) \\
\hline 33,580 & $\mathbf{1 8 , 4 3 6}$ & $\mathbf{5 5}$ & $\mathbf{6 2 8 0}$ \\
\hline
\end{tabular}

Source: Results of the analysis of the data of surveys, 2013.

$34 \%$ are women; each farmer uses in terms of occasional employments, at least one or two farm-labourers who constitute a non-qualified manpower and which, however, is trained on the spot; the unemployed find, close to the producers already established, employments for farm-labourers; students, pupils, apprentices, can place themselves as labourers or temporary workers; market-gardening is an interesting activity which offers employment perspectives and permits to absorb part of the urban unemployment and to occupy numerous idle people by guaranteeing a social peace. 


\subsubsection{Source of Income}

The financial results in a farm strongly depends on the charges and returns achieved. On bringing back to the dimension of a flat band, the charges and returns achieved are presented in Table 6 .

With regard to Table 6, the margin of profit of the farming of garden marjoram by flat band of $20 \mathrm{~m}^{3}$ is of 365 FCFA, with an economic profitability of 59\%. From what precedes, we can say that at the present stage of economic development in Parakou city, and this despite the economic performance registered in a theoretical manner between 2008 and 2013, we notice that owing to the phenomenon of urbanization in the city, and the degree of the perceptible misery; the market-gardening channel is a profitable activity and it increases the income for the households which devote themselves to it. The financial profitability is the margin of profit expressed in the percentage of the sales price. Those results could make the market-gardening activity economically viable on the one hand and Parakou a durable city on the other hand.

\section{Discussion}

\subsection{Dynamics of the Market-Gardening Surfaces in Parakou}

The main handicap to be noted is that $73 \%$ of the total surface of the market-gardening perimeters is made up of land belonging to the estate of the commune and to the private owners who hire their plots to farmers in return for some annual dues, which would constitute a source of land insecurity and of land conflict. The exploitation of the land estates of the State is a source of spatial insecurity [9]. That diachronic analysis puts in evidence the land constraint that urban farmers face in most African cities. Land precariousness thus remains a major problem which brakes the development of market-gardening. It partly explains the choice of short cycle market-gardening crops, as it has also been noted in Dakar [10]. Urban agriculture is a well visible activity owing to its intensiveness and to the more and more important proportion of city-dwellers who practise it. If in some countries like Japan urban farmers are protected and encouraged by the government through some regulations and some reductions of land taxes, in Africa, they are, in most cases, submitted to the repressive measures of the municipal administrators and planners [11]. Contrary to some African cities where urban agriculture is not well-perceived by local powers, the difficulties related to the access to land does not seem to exist in Parakou. It is, at least, what the market-gardeners have affirmed.

Table 6. Account of the exploitation of a flat band of $30 \mathrm{~m}^{3}$ in FCFA for the farming of garden marjoram.

\begin{tabular}{ccc}
\hline Rubriques & Cost per par flat band of $\mathbf{2 0} \mathbf{~ m}^{\mathbf{2}}$ \\
Variable Charges & $\mathbf{9 0 0}$ \\
Seeds & 205 \\
Organic fertilizers & 150 \\
Chemical fertilizers & 200 \\
Plant-treating products & 45 \\
Manpower & 300 \\
Fixe Charges & $\mathbf{1 3 7 5}$ \\
Hiring of field & 360 \\
Amortization of tools & 25 \\
Wages to be paid & $\mathbf{7 8 0}$ \\
Energy (water) & 210 \\
Total Charges (TC) & $\mathbf{2 2 7 5}$ \\
Average Receipts (AR) & $\mathbf{5 6 4 0}$ \\
Net Margin (NM) & $\mathbf{3 3 6 5}$ \\
Internal Rate of Profitability (IRTP) & $\mathbf{5 9 . 7 \%}$ \\
\hline
\end{tabular}

Source: Results of the analysis of the data of surveys, 2013. 


\subsection{Diversification of the Production and Food Security}

The diversity of the cultivated species is related to the insistence of the consumers' demand and, in particular, to the diversity of the cultural communities. According to [12], market-gardening products present a number of comparative advantages in relation to other agricultural products in the context of farming in the urban zone: a big diversity of species and varieties; a potential of yield per time unit and per very high soil unit; a rapid growth; a high intensity of manpower; a high merchant value and nutritious qualities and health.

Urban agriculture could contribute to collective productivity. But beyond its contribution to the feeding of the poorest households, and albeit difficult to evaluate, [11] situates the contribution of urban agriculture at two other levels. At the level of the urban community, he argues that agriculture can: contribute to collective productivity; constitute an employment multiplier; serve as a point of women's entrance in entrepreneurship and the urban work market; and contribute to the valorization of the spaces left vacant. The contribution of those market-gardening products aims at improving food security, the increase of the income and, in case of vulnerability following agricultural and other disasters, at reducing its damage. Thus, urban agriculture easily adapts itself to the consumers' food security strategy and our study demonstrates that the market-gardening channel permits a quantitative and a qualitative availability of market-gardening products. As a matter of fact, a balanced diet includes according to [13] a series of elements the most important of which are glucides, proteins, vitamins and mineral salts. Each of these substances plays a role in the building, the maintenance and the activity of the living organism. And to be really well-nourished and in good health, man should find in his diet a balanced set of those substances.

According to [8], in terms of contribution to food security, the market-gardening channel mainly illustrates itself through the garden marjoram which represents the biggest provider in nutritious elements of all the cultivated vegetables in the market-gardening perimeters of Parakou. Its leaves represent between $60 \%$ to $76 \%$ of the fresh weight of the shoots, rich in proteins (3.6\% - 4.6\%) and in vitamin C (64 mg per $100 \mathrm{~g}$ of eatable stuff). As for fruit vegetables, a slight superiority of okra in proteins $(1.8 / 100 \mathrm{~g})$ and in vitamin C (18 $\mathrm{mg})$ as compared to eggplants (1.6 g of protein and $6 \mathrm{mg}$ of vitamin C/100g). Carrot, as far as root vegetables are concerned, possesses $1.8 \mathrm{~g}$ of protein and $8 \mathrm{mg}$ of vitamin $\mathrm{C} / 100 \mathrm{~g}$. As far as the energizing value is concerned, leaf vegetables are represented by garden marjoram (108 kj/100g and $26 \mathrm{kcal} / 100 \mathrm{~g})$, and fruit vegetables by okra $(129 \mathrm{kj} / 100 \mathrm{~g}$ and $20 \mathrm{kcal} / 100 \mathrm{~g}$ ) and eggplants (108 kj/100g and $26 \mathrm{kcal} / 100 \mathrm{~g})$ in addition to its faculties of fighting against insects and nematodes. The biggest energizing value is found in the category of root vegetables with carrots which possess $154 \mathrm{kj} / 100 \mathrm{~g}$ and $37 \mathrm{kcal} / 100 \mathrm{~g}$. Beside micro-nutrients, namely glucides, proteins, lipids, the organism needs micro-nutrients whose contributions are necessary in small but essential quantities that can easily be found in vegetables. Per capita, the market-gardening channel contributes up to $1.3 \mathrm{kcal}$ and $8.1 \mathrm{~g}$ of proteins. Although it is relatively insufficient, it constitutes an interesting nutritional complement as far as food security is concerned.

\subsection{Protection of the Environment through the Drainage of the Urban Area}

As a risk factor for the environment, the waste in constant increase invades the city and when they are often thrown away in vague pieces of land, in gutters and in rivers, they generate an increasing evacuation and treatment cost and constitutes as a result an increasing pollution problem [5]. The treatment of those wastes in composts usable in the market-gardening perimeters thus participates in the drainage of the city on the one hand and contributes to the protection of the environment on the other hand.

The role of urban agriculture in the management of the environment has also been underlined by many authors, [14] [15]. For those authors, urban agriculture through the market-gardening activity permits to reduce pollution in the city (urban and outskirts quarters). It permits, as a matter of fact, to recycle household garbage and the waste of the cities (in municipal markets, breweries, etc.). That garbage collection constitutes up-stream a contribution to the drainage of the intra and out-of-town area through garbage collection, and down-stream an agronomical advantage due to the availability of fertilizers, in view of the weak texture and structure of the soils of Parakou [16]. According to [17], the merits that compost offers in the market-gardening channel are of six orders: it favours the growing of root vegetables; it improves the rhythm of the diffusion of nutrients; it improves the porosity of the soil; it improves the capacity of water retention; it limits the appearance of diseases; it increases the gross margin of the exploitation, for the presence of organic fertilizers increases the gross margin of the exploitation through the quality of the products which influences the sales price, and through the reduc- 
tion of the charges devoted to the chemical fertilizers and plant-treating products. As far as the manure is concerned, ripe compost increases approximately to $50 \%$ the quantity of stable humus left on the soil. In view of what precedes, it is a compost the conductivity of which is not disputed.

\subsection{Creation of Employments and Increase of Income}

Today, because of the difficult economic situation that Africa is confronted with, urban agriculture becomes more and more important. In the cities of Central Africa for example, it is largely practiced by women. Thus, at Makékélé, (a quarter of in the north of Brazzaville), [18] estimates at 4 to 5 the number of women practicing that activity. In Libreville, Gabon, he situates the number of women practicing agriculture at $80 \%$. In Bangui, the official statistics estimate at $10 \%$ the number of heads of families who are farmers. That number expresses reality badly, for the majority of women practice agriculture in one form or another. More than $20 \%$ of women declare themselves farmers. A durable city is the one which is capable of developing without destroying itself in the long term, the one which gives access to the benefits of urban life by offering the best quality of life for everybody, the one which rejects social exclusions, the one which masters its prejudices through the recycling of its waste, the one where the city-dweller enjoys living, working and developing his social life.

Most researchers, [10] [19]-[21] who have leant over the phenomenon agree at least on one thing: urban agriculture is a key element in the economy of poor households. It constitutes an important source of food and income for the most deprived households. The presence of agriculture in cities generally expresses a certain poverty of the populations. At the level of national development, urban agriculture can contribute to the reduction of imports and to fight malnutrition. As a result, that element of urban reality of such an importance must be incorporated in urban theory [20].

In view all that proceeds, the market-gardening channel contributes to the durability of Parakou city. For that reason, it permits the best quality of life through the created employment, the generated income and the social insertion brought about. As result, it induces lasting socio-economic development through the partial mastering of its waste through the recycling of biodegradable waste.

\section{Conclusions}

The present study on urban market-gardening in Parakou has dwelt at length on diversified species (the fruit vegetables (eggplants, okra), root vegetables (carrots) and leaf vegetables (garden marjoram).), thus adjusting to the demand. Despite the availability and the evolution of market-gardening perimeters (an increase of $153 \%$ between 2008 and 2013), the high land instability (73\% of the total surface of the market-gardening perimeters are made up of lands belonging to the estate of the commune and to private owners) constitutes a handicap to the development of the market-gardening channel. The local leaf vegetables cultivated in Parakou occupy a place of choice given their interesting properties especially, a rapid growth, a production facility and a high nutritive value; they thus contribute to food security. Of all the waste produced in the three markets of Parakou ( $33580 \mathrm{~m}^{3}$ per year) the market-gardening channel consecrates $18436 \mathrm{~m}^{3}$ per year to the revalorization through burying (green fertilizers) and through composting for the needs in compost; the treatment of waste in compost usable in the market-gardening perimeters participates in the drainage of the city and contributes to the protection of the environment. Finally, market-gardening appears as a source of creation of employment (in 2013, the census of 420 market-gardeners has been taken in the market-gardening perimeters of Parakou) on the one hand, a profitable activity (the margin of profit of the cultivation of garden marjoram through the flat band of $20 \mathrm{~m}^{3}$ is of 3365 FCFA, with an economic profitability of 59.7\%) on the other hand. The perspectives on the market-gardening dynamics in Parakou city being promising, the reinforcement of the measures or the actions to regulate the land system, increase the production, reinforce the commercialization device of vegetables and grant micro-credits to market-gardeners would permit to further make the market-gardening channel dynamic and contribute to the durability of Parakou city. However, urban agriculture does not permit at all to enrich oneself, it is in fact a survival activity; it still requires mastering the planning of crops, the agricultural techniques to dominate the competition between producers and establish correct relationships with the well-organized traders who take upon themselves to sell market-gardening products.

The place of market-gardening in urban planning should be better studied in order to improve the management of the fertility of market-gardening soils, to reduce energy costs and environmental risks, and to secure the supplying of cities. Finally, the multi-functionality of out-of-town agriculture should also deserve more attention [22]. 


\section{References}

[1] Cissao, Y. (2011) La problématique de l'agriculture urbaine au Burkina Faso: Cas de la pratique de l'agriculture en saison pluvieuse dans la zone d'extension du secteur 15 de l'arrondissement de Dafra, commune de Bobo-Dioulasso. Université de Ouagadougou, Mémoire de maîtrise en sociologie, 109 p.

[2] RGPH4 (2013) Résultats provisoires du Recensement Général de la Population et de l’Habitat. INSAE, Bénin.

[3] Lenoir, R. (1984) Le tiers monde peut se nourrir. Rapport au Club de Rome, Fayard, 165 p.

[4] FAO (2011) Pour une agriculture intelligente face au climat, politique, pratiques et financement. Organisation pour l'alimentation, Rome, 14.

[5] Abdoulaye, R. (2006) Gestion de l'assainissement des eaux pluviales en milieu urbain pour un développement durable: Cas de la ville de Parakou. Mémoire de DEA de l’Université d’Abomey-Calavi, Bénin, 68 p.

[6] Abdoulaye, A.R. (2010) Un modèle de gestion durable des eaux pluviales urbaines en Afrique tropicale: Application à la ville de Parakou. Thèse de doctorat unique, Université d’Abomey-Calavi, Bénin, 336 p.

[7] Dubroeucq, D. (1977) Note explicative de la carte pédologique de reconnaissance de la République Populaire du Bénin. Feuille de Parakou de l’ORSTOM, Paris, No. 66, 37 p.

[8] Lannoy, G. (2001) Cultures des légumes. In: Raemaekers, R.H., Ed., Agriculture en Afrique Tropicale, DGCI, Bruxelles, 429-513.

[9] Kanda, M. (2009) Le maraichage périurbain a Lomé: Pratiques culturales, risques sanitaires et dynamiques spatiales. Cahiers Agricultures, 18.

[10] Diao, M.P. (2004) Situation et contraintes des systèmes urbains et périurbains de production horticole et animale dans la région de Dakar. Cahiers Agricultures, 13, 39-49.

[11] Freeman, D.B. (1991) A City of Farmers: Informal Urban Agriculture in the Open Spaces of Nairobi, Kenya. McGillQueen’s University Press, Montreal and Kingston, London, Buffalo.

[12] Mougeot, J.A. (2003) Agriculture urbaine en Afrique d'un point de vue mondiale. IDRC/CRDI, 19 p.

[13] Dupriez, H., et al. (1987) Jardins et vergers d’Afrique. L'Harmattan. Paris.

[14] Kabanga, B. (1992) La problématique de la gestion des déchets dans la ville de Kinshasa. Med. Fac. Landbouww, Univ. Gent, 247-254.

[15] Fleury, A. and Donadieu, P. (1997) De l'agriculture périurbaine à l'agriculture urbaine. Le Courrier de l'environnement, No. 31.

[16] Abdoulaye, A. and Oyédé, M. (2009) Un site urbain de l’Afrique tropicale confronté aux contraintes naturelles et anthropiques: Le cas de la ville de Parakou au Bénin. Revue BenGéO, No. 5, Département de Géographie, UAC, 16 p.

[17] Luxen, P., Godden, B., Limborg, P., Lecomte, Ph. and Toussaint, B (1996) Le compostage: Une technique de valorisation des matières organiques en agriculture. Coll. Les livres de l'Agriculture, No. 3, Bruxelles, 25 p.

[18] Schoonbrodt, R. (1995) La ville durable: Une tétralogie européenne. Fondation européenne pour l'amélioration des conditions de vie et de travail, $142 \mathrm{p}$.

[19] Rakodi, C. (1988) Urban Agriculture: Research Questions and Zambia Evidence. Journal of Modern African Studies, 26, 495-515. http://dx.doi.org/10.1017/S0022278X00011745

[20] Memon, P.A. and Lee-Smith, D. (1993) Urban Agriculture in Kenya. Canadian Journal of African Studies, 27, 25-42. http://dx.doi.org/10.2307/485438

[21] Lusugga Kironde, J.M. (1992) Received Concepts and Theories in African Urbanisation and Management Strategies: The Struggle Continues. Urban Studies, 29, 1277-1292. http://dx.doi.org/10.1080/00420989220081271

[22] Awa, B. (2007) Les Fonctions reconnues à l'agriculture intra et périurbaine (AIPU) dans le contexte dakarois, caractérisation, analyse et diagnostic de durabilité de cette agriculture en vue de son intégration dans le projet urbain de Dakar (Sénégal). Thèse de Doctorat, AgroParisTech/Université Cheikh Anta Diop, Dakar. 